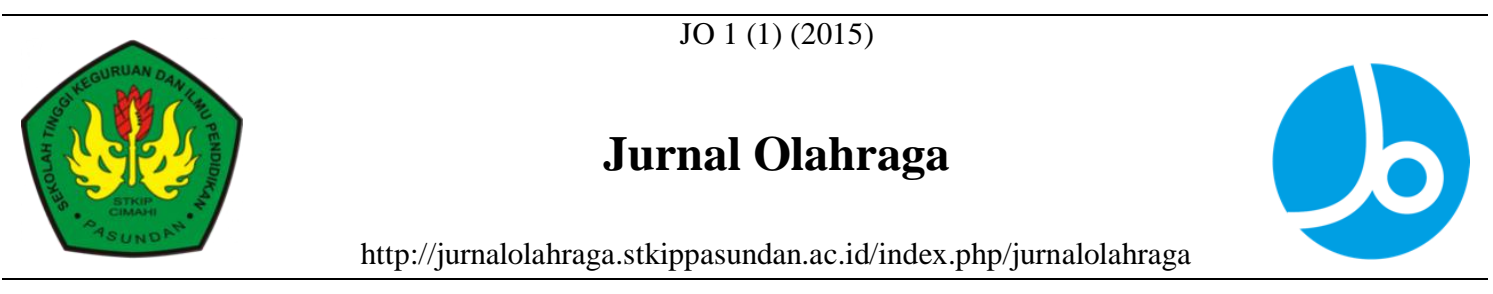

\title{
Studi Korelasional antara Power Lengan, Fleksibilitas, dan Motivasi Berprestasi dengan Hasil Pukulan Forehand Groundstroke
}

\begin{abstract}
Dhani Agusni
STKIP Pasundan, Indonesia

Info Artikel

Sejarah Artikel:

Diterima Januari 2015

Disetujui Maret 2015

Dipublikasikan April 2015

Keywords:

Power Lengan; Fleksibilitas,

Motivasi Berprestasi, Hasil

Pukulan Forehand, Tenis

Lapang

\section{Abstrak}

Penelitian ini bertujuan untuk mencari hubungan dan pengaruh power lengan, fleksibiltas, motivasi berprestasi terhadap hasil pukulan forehand tenis lapang. Metode yang digunakan dalam penelitian ini yaitu dengan menggunakan metode survey dengan pendekatan korelasoinal. Adapun jumlah sampel yang digunakan yaitu sebanyak 11 mahasiswa yang tergabung dan aktif di dalam UKM tenis lapang. Alat pengumpul data yang digunakan berupa angket, yaitu angket mengenai motivasi berprestasi dan tes untuk tes power lengan, fleksibilitas, dan tes pukulan forehand berupa kecepatan dan ketepatan. Hasil penelitian yang diperoleh yaitu power lengan berpengaruh dan memiliki hubungan positif terhadap hasil pukulan forehand, fleksibilitas berpengaruh dan memiliki hubungan positif terhadap hasil pukulan forehand, serta motivasi berprestasi berpengaruh dan memiliki hubungan positif terhadap hasil pukulan forehand. Hasil penelitian yang berikutnya yaitu ketiganya berpengaruh dan memiliki hubungan positif terhadap hasil pukulan forehand.
\end{abstract}

\section{Abstract}

This research is to find the relationship and influence of arm strength, flexibility, achievement motivation on the results of field tennis forehands. The method used in this study uses a survey method using korelasoinal. The number of samples used was 11 students who are members and active in UKM tennis field. Data collection tools used consisted of a questionnaire, namely a questionnaire about achievement motivation and tests for arm power tests, were discussed, and forehand tests consisted of speed and accuracy. The results obtained are arm strength that is collected and has a positive relationship with the results of the forehand, denies and has a positive relationship with the results of the forehand, as well as related achievement motivation and has a positive relationship with the results of the forehand. The next research results are all three and have a positive relationship with the results of the forehand. 
(C) 2015 Dhani Agusni

Under the license CC BY-SA 4.0

\begin{tabular}{lc}
\hline Alamat korespondensi: & ISSN 2442-9661 (cetak) \\
E-mail: &
\end{tabular}

\section{PENDAHULUAN}

Olahraga mempunyai arti yang penting dalam usaha untuk meningkatkan kualitas sumber daya manusia. Olahraga tidak dapat dipisahkan dari kehidupan manusia, karena kehidupan manusia terdiri dari dua aspek, yaitu aspek jasmani dan aspek rohani yang tidak dapat dipisah-pisahkan. Jika kedua aspek tersebut berkembang dan tumbuh secara berselaras maka akan timbul kehidupan yang harmonis dalam pertumbuhannya. Keselarasan kehidupan jasmani dan rohani pada manusia dapat tercapai dengan melakukan olahraga. Salah satu tujuan pembinaan olahraga di Indonesia adalah untuk meningkatkan prestasi yang dapat membangkitkan rasa kebanggan nasional, untuk mewujudkan hal tersebut dilakukan pembinaan secara berencana dan sistematis.

Tenis merupakan salah satu jenis olahraga yang sangat populer dan banyak digemari disemua lapisan masyarakat khususnya di Indonesia, karena olahraga tenis merupakan salah satu rekreasi yang sehat, baik untuk orang dewasa, remaja, maupun anak-anak.Setiap perlombaan di dalam negeri maupun di luar negeri kejuaraan antar klub maupun kelompok umur selalu diikuti oleh banyak peserta. Pada umumnya peserta kejuaraan adalah siswa-siswi Sekolah Dasar (SD), Sekolah Menengah Pertama (SMP), siswa-siswi Sekolah Menengah Atas (SMA), bahkan Mahasiswa.

Prestasi olahraga tenis di Indonesia saat ini belum sesuai dengan harapan masyarakat, prestasi olahraga khususnya cabang Tenis Lapangan sampai saat ini masih giat dilaksanakan suatu pembinaan menuju prestasi yang maksimal, walapun pada kenyataannya prestasi tenis lapangan di Indonesia masih tertinggal dari prestasi negara lain.Sedangkan prestasi di provinsi Jawa Barat salah satu contoh di multievent tingkat nasional yaitu Pekan Olahraga Nasional (PON) beberapa tahun terakhir mengalami penurunan.

Hal tersebut disebabkan oleh beberapa hal, antara lain : (1) Kajian tentang olahraga prestasi dan penerapan ilmu pengetahuan dan teknologi masih kurang, (2) permasalahan olahraga masyarakat yang diharapkan dari perkumpulan dan sekolah belum memenuhi harapan, (3) masih kurangnya jam pelajaran pendidikan jasmani 
di sekolah maupun di perguruan tinggi yang tidak menunjang peningkatan prestasi di kalangan siswa dan mahasiswa, di lain pihak pada lembaga tersebut banyak terdapat bibit atlet yang potensial untuk dikembangkan, (4) masih kurang sekali sarana dan prasarana olahraga yang tersedia di dalam menunjang peningkatan prestasi. Disamping hal tersebut di atas, menurut Bompa (1999:24) menyatakan bahwa:

Kondisi lain yang tidak kalah pentingnya untuk mencapai prestasi olahraga adalah kemampuan atlet itu sendiri. Kemampuan yang dimaksud terdiri dari empat aspek utama yaitu : (1) Persiapan fisik, (2) Persiapan teknik, (3) Persiapan taktik, (4) Persiapan psikologis.

Hal yang sama dikemukakan oleh Harsono (1998:02) menyebutkan bahwa, 'Terdapat empat aspek yang perlu diperhatikan suatu cabang olahraga, yaitu: (1) fisik, (2) teknik, (3) taktik, (4) mental'. Didalam olahraga khususnya tenis lapang, serangkaian gerakan dilakukan melibatkan unsur fisik seperti kekuatan, kecepatan, kelincahan,fleksibilitas, power, daya tahan, dan koordinasi.

Dalam olahraga tenis dituntut memiliki keterampilan dasar dalam bermain. Keterampilan dasar tersebut dapat dilakukan dengan baik jika memiliki tingkat kemahiran atau penguasaan keterampilan dasar dengan baik. Untuk mencapai prestasi yang maksimal, harus diterapkan suatu pendekatan pembelajaran yang tepat. Menurut Lardner (1990:07) menyebutkan bahwa:
Permainan tenis merupakan olahraga yang istimewa, karena latar belakang dan tradisinya, tenis mengajarkan sopansantun, sikap mental yang positif, serta penghargaan terhadap aturan-aturan. Karena tenis merupakan suatu cabang olahraga yang sifatnya individu, maka rasa percaya diri mendapat penekanan, bila kita kalah tidak ada yang dapat dipersalahkan selain diri kita sendiri. Kalau mendapat kemenangan kita akan merasakan suatu kepuasan tersendiri.

Untuk dapat melakukan suatu permainan tenis yang enak dilihat, terlebih dahulu seorang pemain harus menguasai teknik dasar pukulan tenis yang baik. Dalam permainan tenis lapangan, penguasaan teknik dasar yang benar merupakan modal utama untuk belajar teknik permainan. Teknik dasar tersebut harus dimiliki oleh setiap pemain baik pemula maupun lanjutan melalui latihanlatihan yang intensif.

Keterampilan bermain tenis menuntut pula stamina atau kemampuan daya tahan kerja tubuh yang melakukan gerakan-gerakan yang efektif dalam aktifitas seorang pemain tenis. Tenis bukan hanya merupakan olahraga, akan tetapi juga merupakan sarana untuk mengisi waktu luang, demi kesenangan diri sendiri, tetapi ada juga yang berlatih untuk meningkatkan prestasi. Tenis adalah permainan dengan menggunakan raket dan bola, dalam olahraga yang juga disebut Lawn Tennis ini, raket dipukulkan ke bola sambut menyambut oleh seorang atau sepasang pemain yang saling berhadapan dan dimainkan disebuah lapangan empat persegi 
panjang yang dibagi menjadi dua oleh sebuah jaring.

Usaha untuk meningkatkan kemampuan bermain tenis dapat dilakukan dengan berbagai aktivitas secara maksimal melalui proses latihan yang terprogram, baik dari segi fisik maupun psikis. Dengan kata lain, kemampuan bermain tenis akan diperoleh melalui latihan yang terarah dan terprogram, latihan seringkali menimbulkan kebosanan, karena memerlukan usaha, waktu yang lama dan berulang-ulang. Oleh karena itu membutuhkan dorongan kuat dari diri sendiri dan lingkungan, dorongan ini disebut dengan motivasi.

Dalam olahraga kita harus berjuang dengan diri sendiri, maksudnya apabila kita menginginkan suatu prestasi yang tinggi, maka harus berlatih. Latihan itu harus muncul dari dalam diri sendiri atau dengan kata lain keinginan dari hati nurani pribadi, memiliki motivasi untuk berprestasi, karena untuk melaksanakan proses latihan banyak rintangan yang harus dilalui oleh seorang atlet. Disamping itu juga harus bersaing dengan orang lain/teman satu tim, karena olahraga bersifat kompetitif. Artinya berinteraksi dan bersaing dengan orang lain, juga harus berkonfrontasi dengan alam, harus beradaptasi dengan cuaca dingin ataupun panas pada saat latihan ataupun bertanding. Akan tetapi olahraga juga menimbulkan sifat permainan yaitu mengekspresikan kebebasan kita dengan sukarela tanpa paksaan dari orang lain.
Perlu dipahami bahwa sekali terbiasa bermain dengan cara yang kurang tepat atau kurang disiplin dalam permainan, sukarlah untuk mengubah dan memperbaikinya dan tidak mungkin untuk mencapai prestasi yang setinggi-tingginya.Selain itu, untuk mencapai prestasi yang setinggi-tingginya setidaknya seorang atlet harus memiliki motivasi berprestasi. Motivasi merupakan suatu proses psikologis yang mencerminkan interaksi antara sikap, kebutuhan, persepsi, dan keputusan yang terjadi pada diri seseorang. Motivasi sebagai proses psikologis timbul diakibatkan oleh faktor di dalam diri seseorang itu sendiri yang disebut faktor intrinsik atau faktor ekstrinsik.

Faktor di dalam diri seseorang dapat berupa kepribadian, sikap, pengalaman dan pendidikan, atau berbagai harapan, cita-cita yang menjangkau ke masa depan, sedang faktor di luar diri, dapat ditimbulkan oleh berbagai sumber, bisa karena pengaruh pimpinan, kolega atau faktor-faktor lain yang sangat kompleks. Tetapi baik faktor intrinsik maupun faktor ekstrinsik motivasi timbul karena adanya rangsangan.

Motivasi merupakan salah satu faktor psikis yang berpengaruh pada keberhasilan olahraga, disamping faktor lain yang berpengaruh adalah faktor fisik. Mengkaji faktor-faktor yang berpengaruh pada kemampuan bermain tenis adalah merupakan hal penting yang harus diketahui, agar mempunyai gambaran seberapa jauh faktorfaktor tersebut mempunyai peranan dalam 
meningkatkan kemampuan bermain tenis. Berdasarkan alasan-alasan tersebut maka dalam penelitian ini yang dibahas dan dijadikan objek penelitian dilapangan adalah kemampuan fisik berupa power lengan, fleksibilitas pinggang dan faktor psikis yaitu motivasi berprestasi.

Faktor psikis yang berpengaruh pada olahraga, yaitu motivasi yang merupakan proses aktualisasi sumber penggerak dan pendorong tingkah laku individu memenuhi kebutuhan untuk mencapai tujuan dengan predikat unggul atau excellent, atau dengan kata lain kemampuan yang menunjukan kesungguhan untuk melaksanakan pekerjaan. Motivasi berprestasi merupakan daya penggerak yang menimbulkan kegiatan belajar untuk mencapai kemampuan yang optimal.

Pengaruh psikis pada atlet secara khusus terlihat ketika sedang berlomba, dapat dilihat anatara lain kuat lemahnya dorongan untuk meraih prestasi dan menjadi yang terbaik dalam perlombaan, aspek ini sering disebut sebagai aspek mental, yang kadangkadang berpengaruh besar pada seorang atlet. Sekalipun seorang atlet telah melakukan latihan-latihan teknik secara cermat dan maksimal, namun kalau tidak atau kurang ada dorongan untuk berprestasi hasilnya sering mengecewakan.

Pendekatan psikologis diharapkan mampu menghasilkan seorang yang dalam setiap penampilan memperlihatkan dorongan atau motivasi yang kuat untuk bermain tenis dengan sebaik-baiknya. Motivasi yang baik tidak mendasarkan faktor luar (ekstrinsik) misalnya pujian atau ganjaran dalam bentuk materi.Tetapi motivasi yang baik, kuat dan menetap itu mendasarkan pada keingginan pribadi, yang lebih mengutamakan prestasi untuk mencapai kepuasaan diri dari pada halhal lain yang bersifat materi. Dengan kata lain, suatu dorongan yang tumbuh dan berasal dari dalam diri sendiri.

Seorang atlet yang memiliki motivasi berprestasi yang tinggi dalam tenis lapangan, tentunya akan berusaha untuk meningkatkan kemampuannya dalam bermain terutama penguasaannya dalam keterampilan teknik dasar tenis lapangan yang dimilikinya. Untuk mengetahui besarnya tingkat motivasi berprestasi yang dimiliki seorang atlet, maka perlu diberikan quesioner dan observasi di lapangan saat seorang atlet berlatih.

Tujuan dari penelitian ini adalah untuk mengetahui apakah power lengan, fleksibilitas dan motivasi berprestasi terhadap hasil pukulan forehand groundstroke pada permainan tenis lapangan.

\section{METODE}

Penelitian ini menggunakan metode penelitian survey dengan pendekatan kolerasional, karena tujuan dari penelitian yang dilakukan adalah untuk mengetahui ada atau tidaknya hubungan antara power lengan dengan hasil pukulan forehand, fleksibilitas dengan hasil pukulan forehand, motivasi berprestasi dengan hasil pukulan forehand, dan power lengan, fleksibilitas, motivasi 
berprestasi secara bersama-sama dengan hasil pukulan forehand. Dalam penelitian ini terdapat tiga variabel bebas dan satu variabel terikat. Variabel bebas meliputi power lengan, fleksibilitas, dan motivasi berprestasi sedangkan variabel terikat dalam penelitian ini yaitu hasil pukulan forehand berupa skor dari ketepatan dan skor dari kecepatan.

Populasi dalam penelitian ini yaitu seluruh mahasiswa STKIP PASUNDAN yang tergabung dalam UKM tenis lapang yang berjumlah 11 orang. Sampel dalam penelitian ini sebanyak 11 orang mahasiswa. Pengambilan sampel dilakukan dengan teknik total sampling.

Alat ukur yang digunakan berupa angket untuk memperoleh data dari motivasi berprestasi dan sedangkan untuk memperoleh data untuk power lengan, fleksibilitas dan hasil pukulan forehand. Tes power lengan menggunakan ball medicine, untuk fleksibilitas menggunakan sit and reach, dan untuk hasil pukulan forehand menggunakan tes ketepatan dan kecepatan pukulan dan teknik alaisis data menggunakan uji t.

\section{HASIL DAN PEMBAHASAN}

Dari hasil penelitian ini dapat disimpulkan bahwa power lengan berpengaruh terhadap pukulan forehand, fleksibilitas berpengaruh terhadap forehand, motivasi berprestasi berpengaruh terhadap pukulan forehand, dan power lengan, fleksibilitas, dan motivasi berprestasi secara bersama-sama memberikan pengaruh terhadap hasil pukulan forehand. Kesimpulan tersebut dapat dilihat pada tabel 1 di bawah ini:

\section{Tabel 1}

\section{Hasil Penghitungan Uji Korelasi Power lengan $\left(\mathbf{X}_{1}\right)$ dengan Hasil Pukulan \\ Forehand (Y)}

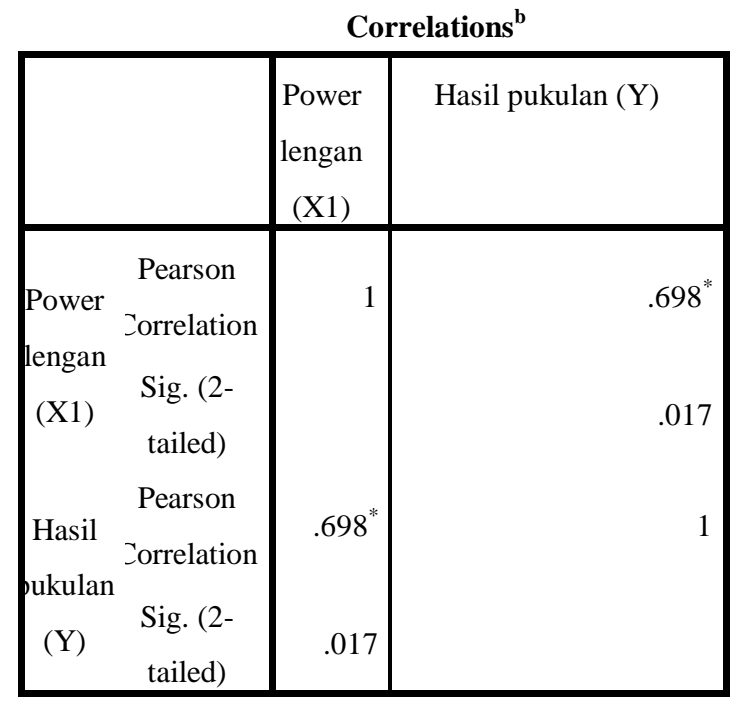

*. Correlation is significant at the 0.05 level (2-tailed). Hasil perhitungan yang diperoleh untuk korelasi antara variabel Power lengan $\left(\mathrm{X}_{1}\right)$ dengan Hasil pukulan (Y) adalah 0,698 dengan nilai signifikansi 0,017 . Nilai korelasi yang diperoleh menunjukkkan bahwa hubungan Power lengan $\left(X_{1}\right)$ dengan hasil pukulan (Y) masuk kategori kuat (berada pada interval $0,6-0,8)$.

Untuk menguji signifikansi hubungan Power lengan $\left(\mathrm{X}_{1}\right)$ dengan hasil pukulan $(\mathrm{Y})$ digunakan uji t. Nilai $\mathrm{t}$ hitung dari hasil perhitungan diperoleh sebesar 2,942. Untuk n $=11$ diperoleh nilai $\mathrm{t}$ tabel dengan $\mathrm{db}=9$ adalah 1,833. Karena $|t|$ hitung $(=2,942)>t$ tabel $(=1,833)$ maka $\mathrm{H}_{0}$ ditolak atau nilai sig $(0,017)<0,05$, maka $\mathrm{H}_{0}$ ditolak. Artinya 
terdapat hubungan positif antara Power lengan $\left(\mathrm{X}_{1}\right)$ dengan hasil pukulan Forehand (Y). Hasil pengujian uji korelasi akan disajikan pada tabel 2.2 sebagai berikut:

Tabel 2

Hasil Penghitungan Uji Korelasi

Fleksibilitas $\left(\mathrm{X}_{2}\right)$ dengan Hasil Pukulan Forehand (Y)

\begin{tabular}{|cc|c|c|}
\hline & Correlations $^{\mathbf{b}}$ & \\
\hline & $\begin{array}{c}\text { Fleksibilitas } \\
(\mathrm{x} 2)\end{array}$ & $\begin{array}{c}\text { Hasil } \\
\text { pukulan } \\
(\mathrm{Y})\end{array}$ \\
\hline $\begin{array}{c}\text { Fleksibilitas } \\
(\mathrm{x} 2)\end{array}$ & $\begin{array}{c}\text { Pearson } \\
\text { Correlation } \\
\text { Sig. (2-tailed) }\end{array}$ & 1 & $.673^{*}$ \\
$\begin{array}{c}\text { Pearson } \\
\text { Hasil pukulan } \\
\text { (Y) }\end{array}$ & $\begin{array}{c}\text { Correlation } \\
\text { Sig. (2-tailed) }\end{array}$ & $.673^{*}$ & .023 \\
\hline
\end{tabular}

*. Correlation is significant at the 0.05 level (2-tailed).

Hasil perhitungan yang diperoleh untuk korelasi antara variabel Fleksibilitas $\left(\mathrm{X}_{2}\right)$ dengan hasil pukulan (Y) adalah 0,673 dengan nilai signifikansi 0,023 . Nilai korelasi yang diperoleh menunjukkkan bahwa hubungan Fleksibilitas $\left(\mathrm{X}_{2}\right)$ dengan Hasil pukulan forehand (Y) masuk kategori kuat (berada pada interval 0,6 -0,8).

Untuk menguji signifikansi hubungan Fleksibilitas $\left(\mathrm{X}_{2}\right)$ dengan Hasil pukulan $(\mathrm{Y})$ digunakan uji t. Nilai $\mathrm{t}$ hitung dari hasil perhitungan diperoleh sebesar 2,728. Untuk $n$ $=11$ diperoleh nilai $\mathrm{t}$ tabel dengan $\mathrm{db}=9$ adalah 1,833. Karena $|\mathrm{t}|$ hitung $(=2,728)>\mathrm{t}$ tabel $(=1,833)$ maka $\mathrm{H}_{0}$ ditolak atau nilai sig $(0,023)<0,05$, maka $\mathrm{H}_{0}$ ditolak. Artinya terdapat hubungan positif antara Fleksibilitas $\left(\mathrm{X}_{2}\right)$ dengan Hasil pukulan forehand $(\mathrm{Y})$.
Berikut hasil uji korelasi yang akan disajikan pada tabel 3, sebagai berikut:

Tebel 3

Hasil Penghitungan Uji Korelasi

Motivasi berprestasi $\left(\mathrm{X}_{3}\right)$ dengan

Hasil pukulan forehand (Y)

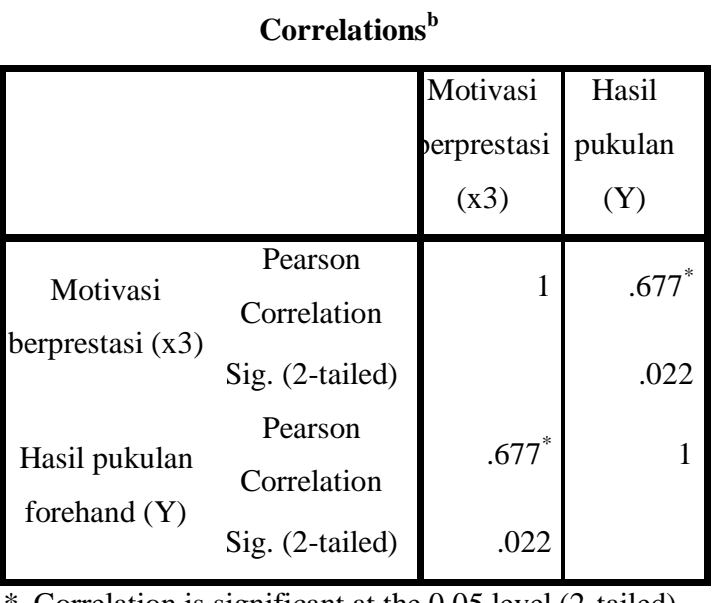

*. Correlation is significant at the 0.05 level (2-tailed).

Hasil perhitungan yang diperoleh untuk korelasi antara variabel Motivasi berprestasi $\left(\mathrm{X}_{3}\right)$ dengan Hasil pukulan forehand (Y) adalah 0,677 dengan nilai signifikansi 0,022 . Nilai korelasi yang diperoleh menunjukkkan bahwa hubungan motivasi berprestasi $\left(\mathrm{X}_{3}\right)$ dengan hasil pukulan forehand (Y) masuk kategori kuat (berada pada interval 0,6 -0,8).

Untuk menguji signifikansi hubungan Motivasi berprestasi $\left(\mathrm{X}_{3}\right)$ dengan hasil pukulan forehand (Y) digunakan uji t. Nilai t hitung dari hasil perhitungan diperoleh sebesar 2,760. Untuk $\mathrm{n}=11$ diperoleh nilai $\mathrm{t}$ tabel dengan $\mathrm{db}$ $=9$ adalah 1,833. Karena $|t|$ hitung $(=2,760)>t$ tabel $(=1,833)$ maka $\mathrm{H}_{0}$ ditolak atau nilai sig $(0,022)<0,05$, maka $\mathrm{H}_{0}$ ditolak. Artinya terdapat hubungan positif antara Motivasi berprestasi $\left(\mathrm{X}_{3}\right)$ dengan hasil pukulan forehand 
(Y). Berikut hasil pengujian korelasi yang disajikan pada tabel 4, sebagai berikut:

\section{Tabel 4}

Hasil Penghitungan Korelasi Ganda

Power lengan $\left(\mathbf{X}_{1}\right)$, Fleksibilitas $\left(\mathbf{X}_{2}\right)$, Motivasi berprestasi $\left(\mathbf{X}_{3}\right)$ dengan

Hasil Pukulan Forehand (Y)

\begin{tabular}{|c|r|r|r|r|}
\multicolumn{5}{|c}{ Model Summary } \\
\hline Model & \multicolumn{1}{c|}{$\mathrm{R}$} & R Square & $\begin{array}{c}\text { Adjusted R } \\
\text { Square }\end{array}$ & $\begin{array}{l}\text { Std. Error of } \\
\text { the Estimate }\end{array}$ \\
\hline 1 & $.929^{\mathrm{a}}$ & .862 & .803 & .36887 \\
\hline
\end{tabular}

a. Predictors: (Constant), Motivasi berprestasi $\left(\mathrm{x}_{3}\right)$,

Fleksibilitas $\left(\mathrm{x}_{2}\right)$, Power lengan $\left(\mathrm{X}_{1}\right)$

Hasil perhitungan yang diperoleh untuk korelasi ganda antara variabel power lengan $\left(\mathrm{X}_{1}\right)$, Fleksibilitas $\left(\mathrm{X}_{2}\right)$, Motivasi berprestasi $\left(\mathrm{X}_{3}\right)$ dengan Hasil Pukulan forehand (Y) adalah 0,929. Nilai korelasi yang diperoleh menunjukkkan bahwa hubungan Power lengan $\left(\mathrm{X}_{1}\right)$, Fleksibilitas $\left(\mathrm{X}_{2}\right)$, Motivasi berprestasi $\left(\mathrm{X}_{3}\right)$ dengan Hasil Pukulan Forehand (Y) masuk kategori sangat kuat (berada pada interval 0,9-1,0).

Untuk menguji signifikansi hubungan Power lengan $\left(\mathrm{X}_{1}\right)$, Fleksibilitas $\left(\mathrm{X}_{2}\right)$, Motivasi berprestasi $\left(\mathrm{X}_{3}\right)$ dengan Hasil Pukulan Forehand (Y) digunakan uji F. Nilai F hitung dari hasil perhitungan diperoleh sebesar 14,592 .

Untuk $\mathrm{n}=11$ diperoleh nilai $\mathrm{F}$ tabel dengan $\mathrm{db} 1=3 \mathrm{dan} \mathrm{db} 2=7$ adalah 4,347. Karena F hitung $(=14,592)>$ F tabel $(=4,347)$ maka $\mathrm{H}_{0}$ ditolak atau nilai sig $(0,002)<0,05$, maka $\mathrm{H}_{0}$ ditolak. Artinya terdapat hubungan positif antara Power lengan $\left(\mathrm{X}_{1}\right)$, Fleksibilitas $\left(\mathrm{X}_{2}\right)$, dan Motivasi berprestasi $\left(\mathrm{X}_{3}\right)$ secara bersama-sama dengan Hasil Pukulan Forehand (Y). Berikut hasil perhitungan oefesien regresi yang disajikan pada tabel 5, yaitu sebagai berikut:

\section{Tabel 5}

Hasil Koefisien Regresi $X_{1}$ terhadap Y

\section{Coefficients $^{\mathrm{a}}$}

\begin{tabular}{|c|c|c|c|c|c|}
\hline \multirow[t]{2}{*}{ Model } & \multicolumn{2}{|c|}{$\begin{array}{l}\text { Instandardized } \\
\text { Coefficients }\end{array}$} & \multirow{2}{*}{\begin{tabular}{|c|}
$\begin{array}{c}\text { tandardized } \\
\text { Coefficients }\end{array}$ \\
Beta
\end{tabular}} & \multirow[t]{2}{*}{$\mathrm{T}$} & \multirow[t]{2}{*}{ Sig. } \\
\hline & B & $\begin{array}{l}\text { Std. } \\
\text { Error }\end{array}$ & & & \\
\hline $\begin{array}{c}\text { (Constant) } \\
\text { Power } \\
\text { lengan } \\
\text { (X1) }\end{array}$ & 1.314 & .636 & .698 & $\begin{array}{l}2.065 \\
2.924\end{array}$ & .069 \\
\hline
\end{tabular}

a. Dependent Variable: Hasil Pukulan Forehand (Y)

Nilai konstanta (a) diperoleh sebesar 1,314 dan koefisen regresi (b) diperoleh sebesar 0,514. Berdasarkan hasil perhitungan di atas diperoleh persamaan regresi linier sederhana Power lengan $\left(\mathrm{X}_{1}\right)$ terhadap Hasil pukulan Forehand (Y) sebagai berikut :

$$
\hat{\mathrm{Y}}_{1}=1,314+0,514 \mathrm{X} 1
$$

Diperoleh nilai konstanta (a) dalam persamaan regresi di atas sebesar 1,314 0 . Nilai konstanta (a) menunjukan besarnya rata-skor Hasil pukulan $(\mathrm{Y})=1,314$, pada saat Power lengan $\left(\mathrm{X}_{1}\right)$ tidak berubah atau tetap (0). Koefisien regresi $\mathrm{X}$ sebesar 0,514 menunjukan skor Hasil pukulan Forehand (Y) akan meningkat sebesar 0,514 pada saat skor 
Power lengan $\left(\mathrm{X}_{1}\right)$ meningkat. Artinya semakin baik Power lengan $\left(\mathrm{X}_{1}\right)$ akan meningkatkan Hasil Pukulan Forehand (Y).

Statistik uji yang digunakan untuk menguji signifkansi regresi $\mathrm{X}_{1}$ terhadap $\mathrm{Y}$ adalah uji t. Diperoleh hasil perhitungan statistik uji t dari tabel hasil koefisien regresi sebesar 2,924.Penentuan hasil pengujian (penerimaan/penolakan H0) dapat dilakukan dengan membandingan $t_{\text {hitung }}$ dengan $t_{\text {tabel }}$ atau juga dapat dilihat dari nilai signifikansinya. Dari tabel $\mathrm{t}$ diperoleh nilai $\mathrm{t}$ tabel untuk $\alpha=$ 0,05 dan derajat bebas $(\mathrm{db})=11-2=9$ pada pengujian satu pihak sebesar 1,833 . Karena nilai $t_{\text {hitung }}$ sebesar $=2,924$ lebih besar dari $t_{\text {tabel }}$ sebesar 1,833, maka diperoleh hasil pengujian Ho di tolak dan hipotesis alternatif diterima. Jadi dapat disimpulkan bahwa terdapat hubungan positif Power lengan $\left(\mathrm{X}_{1}\right)$ terhadap Hasil Pukulan Forehand (Y). Berikut hasil perhitungan hasil koefesien regresi yang ditampilkan pada tabel 6 , yaitu sebagai berikut:

\section{Tabel 6}

\section{Hasil Koefisien Regresi $\mathrm{X}_{2}$ dengan $\mathrm{Y}$}

\section{Coefficients $^{\mathrm{a}}$}

\begin{tabular}{|c|c|c|c|c|c|}
\hline \multirow[t]{2}{*}{ Model } & \multicolumn{2}{|c|}{$\begin{array}{c}\text { Unstandardiz } \\
\text { ed } \\
\text { Coefficients }\end{array}$} & $\begin{array}{l}\text { tandardized } \\
\text { Coefficients }\end{array}$ & \multirow[t]{2}{*}{$\mathrm{t}$} & \multirow[t]{2}{*}{ Sig. } \\
\hline & B & $\begin{array}{l}\text { Std. } \\
\text { Error }\end{array}$ & Beta & & \\
\hline $\begin{array}{cc} & \text { (Constant) } \\
1 & \text { Fleksibilitas } \\
& (\mathrm{x} 2)\end{array}$ & $\begin{array}{l}.568 \\
.050\end{array}$ & $\begin{array}{l}.945 \\
.018\end{array}$ & .673 & $\begin{array}{r}.600 \\
2.728\end{array}$ & $\begin{array}{l}.563 \\
.023\end{array}$ \\
\hline
\end{tabular}

a. Dependent Variable: Hasil Pukulan Forehand (Y)
Hasil persamaan regresi linier sederhana untuk Fleksibilitas $\left(\mathrm{X}_{2}\right)$ dengan Hasil Pukulan Forehand (Y) dapat dilihat pada Tabel 4.23.Nilai konstanta (a) diperoleh sebesar 0,568 dan koefisen regresi (b) diperoleh sebesar 0,050. Berdasarkan hasil perhitungan di atas diperoleh persamaan regresi linier sederhana Fleksibilitas $\left(\mathrm{X}_{2}\right)$ dengan Hasil Pukulan Forehand (Y).sebagai berikut :

$$
\hat{\mathrm{Y}}_{1}=0,568+0,050 \mathrm{X} 2
$$

Diperoleh nilai konstanta (a) dalam persamaan regresi di atas sebesar 0,5680. Nilai konstanta (a) menunjukan besarnya rata-skor Hasil pukulan $(\mathrm{Y})=0,568$ pada saat Fleksibilitas $\left(\mathrm{X}_{2}\right)$ tidak berubah atau tetap (0). Koefisien regresi $\mathrm{X}_{2}$ sebesar 0,050 menunjukan skor Hasil Pukulan Forehand (Y) akan meningkat sebesar 0,050 pada saat skor Fleksibilitas $\left(\mathrm{X}_{2}\right)$ meningkat. Artinya semakin baik Fleksibilitas $\left(\mathrm{X}_{2}\right)$ akan meningkatkan Hasil Pukulan Forehand (Y). Statistik uji yang digunakan untuk menguji signifkansi regresi $\mathrm{X}_{2}$ terhdap $\mathrm{Y}$ adalah uji t. Diperoleh hasil perhitungan statistik uji t dari tabel hasil koefisien regresi sebesar 2,728.

Penentuan hasil pengujian (penerimaan/penolakan H0) dapat dilakukan dengan membandingan $t_{\text {hitung }}$ dengan $t_{\text {tabel }}$ atau juga dapat dilihat dari nilai signifikansinya. Dari tabel $\mathrm{t}$ diperoleh nilai $\mathrm{t}$ tabel untuk $\alpha=$ 0,05 dan derajat bebas $(\mathrm{db})=11-2=9$ pada pengujian satu pihak sebesar 1,833 . Karena nilai $t_{\text {hitung }}$ sebesar $=2,728$ lebih besar dari 
$\mathrm{t}_{\text {tabel }}$ sebesar 1,833, maka diperoleh hasil pengujian Ho di tolak dan hipotesis alternatif diterima. Jadi dapat disimpulkan bahwa terdapat hubungan positif Fleksibilitas $\left(\mathrm{X}_{2}\right)$ dengan Hasil Pukulan Forehand (Y).

Hasil Pukulan Forehand (Y).Hasil persamaan regresi linier sederhana untuk Motivasi berprestasi $\left(\mathrm{X}_{3}\right)$ dengan Hasil Pukulan Forehand (Y) dapat dilihat pada Tabel 4.24.Nilai konstanta (a) diperoleh sebesar -4,931dan koefisen regresi (b) diperoleh sebesar 0,064. Berikut hasil perhitungan koefesien regresi yang akan disajikan pada tabel 7, sebagai berikut:

Tabel 7

Hasil Koefisien Regresi $\mathrm{X}_{3}$ dengan $\mathrm{Y}$

\section{Coefficients $^{\mathrm{a}}$}

\begin{tabular}{|c|c|c|c|c|c|}
\hline \multirow[t]{2}{*}{ Model } & \multicolumn{2}{|c|}{$\begin{array}{l}\text { Jnstandardiz } \\
\text { ed } \\
\text { Coefficients }\end{array}$} & $\begin{array}{c}\text { tandardi } \\
\text { zed } \\
\text { Coefficie } \\
\text { nts }\end{array}$ & $\mathrm{t}$ & Sig. \\
\hline & $\mathrm{B}$ & $\begin{array}{l}\text { Std. } \\
\text { Error }\end{array}$ & Beta & & \\
\hline (Constant) & 4.931 & 2.913 & & 1.693 & .125 \\
\hline $\begin{array}{l}\text { Motivasi } \\
\text { berprestasi } \\
\text { (x3) }\end{array}$ & .064 & .023 & .677 & 2.760 & .022 \\
\hline
\end{tabular}

a. Dependent Variable: Hasil Pukulan Forehand (Y).

Berdasarkan hasil perhitungan di atas diperoleh persamaan regresi linier sederhana Motivasi berprestasi $\left(\mathrm{X}_{3}\right)$ dengan hasil pukulan (Y) sebagai berikut:

$$
\hat{\mathrm{Y}}_{1}=-4,931+0,064 \mathrm{X} 1
$$

Diperoleh nilai konstanta (a) dalam persamaan regresi di atas sebesar $-4,931$. Nilai konstanta (a) menunjukan besarnya rata-skor Hasil pukulan $(\mathrm{Y})=-4,931$ pada saat Motivasi berprestasi $\left(\mathrm{X}_{3}\right)$ tidak berubah atau tetap (0). Koefisien regresi $\mathrm{X}_{3}$ sebesar 0,064 menunjukan skor Hasil Pukulan Forehand (Y) akan meningkat sebesar 0,064 pada saat skor Motivasi berprestasi $\left(\mathrm{X}_{3}\right)$ meningkat. Artinya semakin baik Motivasi berprestasi $\left(\mathrm{X}_{3}\right)$ akan meningkatkan Hasil Pukulan Forehand (Y).

Statistik uji yang digunakan untuk menguji signifkansi regresi $\mathrm{X}_{3}$ terhdap $\mathrm{Y}$ adalah uji t. Diperoleh hasil perhitungan statistik uji t dari tabel hasil koefisien regresi sebesar 2,760. Penentuan hasil pengujian (penerimaan/penolakan H0) dapat dilakukan dengan membandingan $t_{\text {hitung }}$ dengan $t_{\text {tabel }}$ atau juga dapat dilihat dari nilai signifikansinya. Dari tabel $\mathrm{t}$ diperoleh nilai $\mathrm{t}$ tabel untuk $\alpha=$ 0,05 dan derajat bebas $(\mathrm{db})=11-2=9$ pada pengujian satu pihak sebesar 1,833 . Karena nilai $t_{\text {hitung }}$ sebesar $=2,760$ lebih besar dari $t_{\text {tabel }}$ sebesar 1,833, maka diperoleh hasil pengujian Ho di tolak dan hipotesis alternatif diterima. Jadi dapat disimpulkan bahwa terdapat hubungan positif Motivasi berprestasi $\left(\mathrm{X}_{3}\right)$ dengan Hasil Pukulan Forehand (Y). Berikut hasil perhitungan koefesien regresi yang akan disajikan pada tabel 8 , sebagai berikut: 
Tabel 8

Hasil Koefisien Regresi Power Lengan $\left(\mathbf{X}_{1}\right)$, Fleksibilitas $\left(\mathbf{X}_{2}\right)$, dan Motivasi berprestasi $\left(\mathrm{X}_{3}\right)$ dengan Hasil Pukulan Forehand (Y)

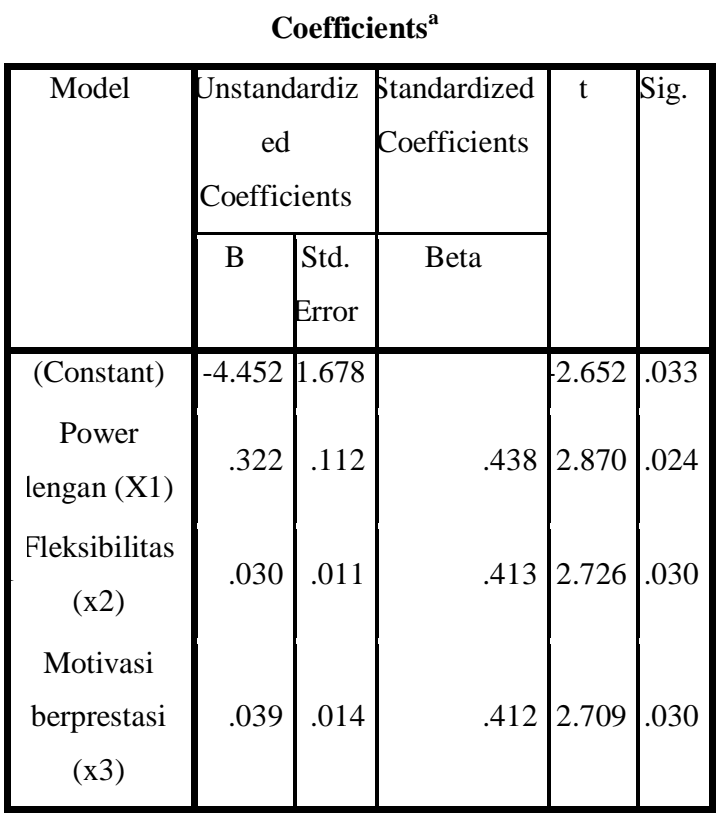

a. Dependent Variable: Hasil pukulan (Y)

Berdasarkan hasil perhitungan di atas diperoleh persamaan regresi linier Power lengan $\left(\mathrm{X}_{1}\right)$, Fleksibilitas $\left(\mathrm{X}_{2}\right)$, Motivasi berprestasi $\left(\mathrm{X}_{3}\right)$ dengan hasil pukulan forehand (Y) sebagai berikut :

$\hat{\mathrm{Y}}_{1}=-4,452+0,322 \mathrm{X} 1+0,030 \mathrm{X} 2+0,039 \mathrm{X} 3$

Diperoleh nilai konstanta (a) dalam persamaan regresi di atas sebesar $-4,452$. Nilai konstanta (a) menunjukan besarnya rata-skor Hasil pukulan $(\mathrm{Y})=-4,452$ pada saat Power lengan $\left(\mathrm{X}_{1}\right)$, Fleksibilitas $\left(\mathrm{X}_{2}\right)$, Motivasi berprestasi $\left(\mathrm{X}_{3}\right)$ tidak berubah atau tetap (0).

Koefisien regresi $X_{1}$ sebesar 0,322 menunjukan pada saat Fleksibilitas $\left(\mathrm{X}_{2}\right)$, Motivasi berprestasi $\left(\mathrm{X}_{3}\right)$ tidak ada perubahan, Power lengan $\left(\mathrm{X}_{1}\right)$ memberikan sumbangan terhadap peningkatan hasil forehand (Y) sebesar 0,322. Artinya semakin baik Power lengan $\left(\mathrm{X}_{1}\right)$ akan meningkatkan Hasil pukulan forehand (Y).

Koefisien regresi $\mathrm{X}_{2}$ sebesar 0,030 menunjukan pada saat Power lengan $\left(\mathrm{X}_{1}\right)$ dan Motivasi berprestasi $\left(\mathrm{X}_{3}\right)$ tidak ada perubahan, Fleksibilitas $\left(\mathrm{X}_{2}\right)$ memberikan sumbangan terhadap peningkatan hasil pukulan forehand $(\mathrm{Y})$ sebesar 0,030. Artinya semakin baik Fleksibilitas $\left(\mathrm{X}_{2}\right)$ akan meningkatkan Hasil pukulan forehand (Y).

Koefisien regresi $X_{3}$ sebesar 0,039 menunjukan pada saat Power lengan $\left(\mathrm{X}_{1}\right)$ dan Fleksibilitas $\left(\mathrm{X}_{2}\right)$ tidak ada perubahan, Motivasi berprestasi $\left(\mathrm{X}_{3}\right)$ memberikan sumbangan terhadap peningkatan Hasil pukulan (Y) sebesar 0,039. Artinya semakin baik Motivasi berprestasi $\left(\mathrm{X}_{3}\right)$ akan meningkatkan Hasil pukulan forehand (Y).

Statistik uji yang digunakan untuk menguji signifkansi regresi $\mathrm{X}_{1}, \mathrm{X}_{2}, \mathrm{X}_{3}$ terhadap $\mathrm{Y}$ adalah uji $\mathrm{F}$. Diperoleh hasil perhitungan statistik uji $\mathrm{F}$ dari tabel hasil koefisien regresi sebesar 14,592. Penentuan hasil pengujian (penerimaan/penolakan $\mathrm{H}_{0}$ ) dapat dilakukan dengan membandingan $\mathrm{F}_{\text {hitung }}$ dengan $\mathrm{F}_{\text {tabel }}$ atau juga dapat dilihat dari nilai signifikansinya. Untuk $\mathrm{n}=11$ diperoleh nilai $\mathrm{F}$ tabel dengan $\mathrm{db} 1=3 \mathrm{dan} \mathrm{db} 2=7$ adalah 4,347. Karena $\mathrm{F}$ hitung $(=14,592)>\mathrm{F}$ tabel $(=4,347)$ maka $\mathrm{H}_{0}$ ditolak atau nilai sig $(0,002)<0,05$, maka $\mathrm{H}_{0}$ ditolak. Artinya sumbangan atau kontribusi Power lengan 
$\left(\mathrm{X}_{1}\right)$, Fleksibilitas $\left(\mathrm{X}_{2}\right)$, dan Motivasi berprestasi $\left(\mathrm{X}_{3}\right)$ secara bersama-sama dengan hasil pukulan (Y) bermakna.

Pada cabang tenis gerakan tersebut terdapat pada saat akan melakukan pukulan salah satunya forehand groundstroke, hal ini sangat memerlukan power otot yang berguna untuk kecepatan dan ketepatan hasil pukulan. Menurut Harsono (1988:199) memaparkan bahwa:

Dasar unsur kondisi fisik yang diperlukan dalam usaha meningkatkan prestasi olahraga.Salah satu faktor kondisi fisik yang menentukan pukulan forehand groundstroke yang maksimal pada cabang olahraga tenis adalah power lengan. Ada dua unsur kondisi fisik yang dapat menghasilkan power atau daya ledak yaitu penggabungan antar unsur kekuatan dan kecepatan. Seperti yang dikemukakan oleh Harsono bahwa daya ledak merupakan kemampuan otot untuk menggerakan kekuatan secara maksimal dalam waktu yang sangat cepat.

Sedangkan Sajoto (1988:8) juga memaparkan bahwa daya ledak adalah kemampuan seseorang untuk mempergunakan kekuatan maksimum dan dikerahkan dalam waktu yang sependekpendeknya, dan dinyatakan bahwa daya ledak merupakan hasil kali antara kekuatan (strength) dengan kecepatan (velocity).

Sehubungan dengan pendapatpendapat para ahli di atas menyebut dua unsur penting dalam power yaitu : (1) kekuatan otot, (2) kecepatan otot dalam mengerahkan tenaga maksimal untuk mengatasi tahanan. Oleh karena itu latihan power tidak boleh hanya menekankan pada beban, akan tetapi harus pula pada kecepatan mengangkat, mendorong, atau menarik beban. Power terutama penting untuk cabang-cabang olahraga dimana atlet harus mengerahkan tenaga yang eksplosif seperti nomor-nomor lempar dalam atletik dan melempar bola softball.Juga dalam cabang-cabang olahraga yang mengharuskan atlet untuk menolak dengan kaki, seperti nomor-nomor lompat dalam atletik, sprint, voli (untuk smes), lari, balap sepeda, mendayung, renang, dan sebagainya. Selain itu power juga perlu untuk memukul seperti dalam cabang olahraga tenis, karate, tinju softball, dan lain-lain.

Berdasarkan beberapa pendapat para ahli mengenai power, maka dapat ditarik kesimpulan bahwa power adalah hasil dari kekuatan dan kecepatan.Keceptan lebih pada kualitas yang dibawa sejak lahir, yang dapat berubah sedikit saja dengan melakukan pelatihan. Jadi power dapat meningkat hanya tergantung penambahan beban yang diberikan dan dipadukan dengan unsur-unsur kesegaran jasmani seperti, Power (Daya/tenaga), Strength (Kekuatan), Speed (Kecepatan), Endurance (Daya tahan), Balance (Keseimbangan), Agility (Kelincahan), Coordination (Koordinasi), Accuracy (Ketelitian /Ketepatan), dan, Accuracy (Ketelitian/Ketepatan).

Membicarakan masalah fleksibilitas selalu mengacu pada kemampuan ruang 
gerak sendi atau persendian tubuh. Banyak ahli memberikan penjelasan mengenai pengertian fleksibilitas yaitu antara lain, Menurut Harsono (1988:163) memaparkan bahwa, 'Fleksibilitas adalah kemampuan untuk melakukan gerakan dalam ruang gerak sendi'. Menurut Rushall \& Pyke (1990:273) menjelaskan bahwa:

Flexibility is an important characteristic for human performance because it governs the range of movement that is used in a technique and the length of the movement over which forces can be generated. It relates to the range of movement around a joint.

Maksud dari pernyataan tersebut adalah fleksibilitas merupakan suatu karakteristik yang penting bagi penampilan atlet, karena fleksibilitas merupakan ruang gerak yang digunakan untuk suatu teknik olahraga dan memperluas gerakan di mana dengan gerakan itu kekuatan akan diciptakan. Fleksibilitas berhubungan dengan ruang gerak di sekitar sendi.

Untuk mengkaji motivasi berprestasi terlebih dahulu harus ditinjau pengertian dari motivasi itu sendiri. Istilah motif sama dengan kata motive yang diartikan sebagai daya penggerak yang mendorong seseorang melakukan aktivitas-aktivitas tertentu untuk mencapai suatu tujuan.Motif selalu dimiliki oleh setiap orang dan masih bersifat pasif. Motif yang sudah aktif disebut motivasi. Motivasi merupakan suatu proses yang tidak bisa diamati secara langsung, akan tetapi motivasi dapat diinterpretasikan melalui tindakan individu dari tingkah lakunya.

$$
\text { Woolfolk (1995:342) menyatakan }
$$

bahwa ada dua penjelasan umum berkenaan dengan motivasi berprestasi, yaitu bahwa:

Achievement motivation us a stable and unconscious trait something individual has more or less of", and " ...achievement motivation as a set of conscious beliefs and values shaped mainly by recent experiences with success and failure and by factor in the immediate situation such as the difficulty of the task or the incentives available.

Pendapat di atas menjelaskan bahwa dalam kondisi stabil dan penuh kesadaran seorang individu memiliki motivasi berprestasi lebih atau kurang, dan motivasi berprestasi sebagai seperangkat keyakinan dan nilai-nilai kesadaran dibentuk oleh pengalaman baru dengan faktor keberhasilan dan kegagalan dalam situasi mendesak seperti kesulitan tugas atau insentif yang tersedia.

Pada proses motivasi, sebagai dorongan memenuhi kebutuhan sehingga orang tersebut akan berusaha dengan daya upaya untuk mencapai hasil kebutuhan cenderung diusahakan terpenuhi, sehingga proses hidup dan kehidupan mengejar nilai yang positif dan amal ibadah bernilai positif. Oleh karena itu orang lalu memilih suatu perbuatan yang memberi nilai positif, sehingga mengarah perilaku yang bersifat positif. 


\section{KESIMPULAN}

Berdasarkan hasil pembahasan yang telah diuraikan diatas, penulis mengambil kesimpulan bahwa terdapat hubungan positif antara power lengan, fleksibilitas, dan motivasi berprestasi dengan hasil pukulan forehand groundstroke dalam permainan.

\section{DAFTAR PUSTAKA}

Anggela Buxton\&C.M.Jones, Starting Tennis, Bandung: Pionir Jaya,1999.

Ackland. Elliot. Bloomfield, Applied Anatomy And Biomechanics in Sport, Australia :Blackwell Scientific Publications, 1994.

B Uno.Hamzah, Teori Motivasi dan Pengukurannya, Jakarta: Bumi Aksara, 2006.

Bompa.Tudor O, Theory and metodology of training,lowa:Kenal Hunt Publishing Company, Dubuque, 1994.

Dangsina.Moeloek, Kesehatan dan Olahraga, Jakarta: Fakultas Kedokteran Universitas Indonesia, 1984.

Harsono.Coaching dan Aspek-Aspek dalam Coaching, Jakarta:Depdikbud Dirjen Dikti,1998.
Harsono, Coaching dan Aspek-aspek Psikologis dalam Coaching, Jakarta,CvIrwan,1988.

Hasanudin dan Cholil Nurhasan, Tes dan Pengukuran, Bandung: Upi, 2007.

John H.J dan Mathis, R.L, Manajemen Sumber Daya Manusia, Jakarta : PT.Salemba Emban Patria, 2001.

Kasiyo.Dwijowinoto,Dasar-dasar Ilmiah Kepelatihan, IKIP Semarang: Press Karya asli, 1984.
Kirkendal, Pengukuran dan Evaluasiuntuk Guru pendidikan Jasmani, Jakarta:PPs IKIP Jakarta,1997.

Lutan Rusli, Belajar Keterampilan Motorik, Jakarta: P2LPTK, 1988.

Magethi.Bey.Tenis Para Bintang, Bandung:Pionir Jaya, 1999.

McClelland,D.C,Memacu Masyarakat Berprestasi Mempercepat Laju Pertumbuhan Melalui Peningkatan Motif Berprestasi, Jakarta :Intermedia, 1987.

Muhajir, Pendidikan Jasmani Olahraga dan Kesehatan. Jakarta: Erlangga, 2006.

P.MAnwar, Manajemen Sumber Daya Manusia Perusahaan, Bandung: Remaja Rosdakarya, 2001.

Pearce.Evelyn C, Anatomi dan Fisiologi,Jakarta:PtGramedia, 2009.

Pyke\&Rushall, Training for Sport and Fitness, Company of Australia: 1990.

Row dan Harper, Tennis A professional Guide, Japan: Hattori Seiko, 1984.

Rex Lardner. Teknik Dasar Tenis Strategi dan Taktik Yang Akurat, Semarang :Dahara Prize, 1990.

S.M. Martianah, Motif Sosial Remaja,Yogyakarta :GadjahMada, 1984.

Sudjana, Tes dan Pengukuran, Bandung: 2006.

Sajoto.M, Peningkatan dan Pembinaan Kekuatan Kondisi Fisik dalam Olahraga, Semarang:Dahara Prize, 1995.

Tudor O,Bomba,Theory and methodolof training, lowa:Kendal Hunt Pub.Inc, 1994. 
Veithzal. R, Education Management, Jakarta : PT. Raja Grafindo Persada, 2003.

Woolfolk, A.E, Educational Psychology, Boston :Allyn and Bacon, 1995.

W.S.Winkel, Psikologi Pendidikan dan Evaluasi Belajar, Jakarta: Gramedia, 1984.

W.S. Winkel, Psikologi Pengajaran,Jakarta: Grasindo, 1996 